\title{
Hubungan Citra Tubuh, Pengetahuan Gizi dan Perilaku Makan terhadap Status Gizi Remaja di SMA Negeri 5 Kota Metro tahun 2017
}

\section{The Correlation between Body Image, Nutrient Knowledge, and Eating Behaviour towards Teenager Nutrition Status of SMA Negeri 5 Metro (Senior High School) In 2017}

\author{
Amalia Amraini ${ }^{1}$, Dhiny Easter Yanti $^{2}$, Nurhalina Sari ${ }^{2}$ \\ ${ }^{1}$ Dinas Kesehatan Kota Metro, Lampung, Indonesia \\ ${ }^{2}$ Fakultas Keehatan Masyarakat Universitas Malahayati, Lampung, Indonesia \\ *korespondensi Penulis: amraini89@gmail.com
}

Penyerahan: 14-04-2020, Perbaikan: 23-04-2020, Diterima: 22-05-2020

\begin{abstract}
Teenager nutrition status is associated with various factors, in between the energy and nutrition, the genital, education, eating of the serpent, the habit of the sorbent, the physical consumption, the physical activities of failing, the body image, and genetic. This research's objectives were to know the correlation between body image, nutrient knowledge, and eating behavior towards the teenager nutrition status of SMA Negeri 5 Metro. The writer used quantitative research and cross-sectional method. The research was conducted from July up to August 2017 with 421 population and 130 students as samples. For the sampling technique, the writer used a random sampling technique. For the data collecting technique, the writer used height and weight measuring instruments and questionnaires. To analyze the data, the writer used univariate and bivariate analysis. From the research (of chi-square test)among 130 students, the writer got the result that 23 students $(17,7 \%)$ were thin, 91 students (70\%) were normal, and 16 students $(12,3 \%)$ were overweight. However, the correlation towards teenager nutrition status in SMA Negeri 5 Metro were: P-Value of body image 0,874, P-Value of nutrient knowledge $=0,765$ and P-Value of eating behaviour 0,354. It can be concluded that there was no correlation between body image, nutrient knowledge, and eating behavior towards teenage nutrition status in SMA Negeri 5 Metro. The suggestion is to give the teenager information about nutrition necessity and well-eating behavior to keep our body healthy and well-balanced.
\end{abstract}

Keywords: Nutrition status, body image, nutrient knowledge, eating behaviour, teenager.

\section{ABSTRAK}

Status gizi remaja berhubungan dengan berbagai macam faktor yang mempengaruhinya, di antaranya adalah asupan energi dan zat gizi, jenis kelamin, pendidikan, pengetahuan, perilaku makan, kebiasaan konsumsi serat (buah dan sayur), aktivitas fisik, perilaku, merokok, citra tubuh dan faktor genetik yaitu status gizi orang tua. Penelitian ini bertujuan mengkaji hubungan citra tubuh, pengetahuan gizi dan perilaku makan terhadap status gizi remaja di SMA Negeri 5 Kota Metro. Jenis penelitian kuantitatif dengan metode crossectional. Waktu penelitian yaitu bulan Juli-Agustus 2017 dengan populasi 421 dan mengambil sampel 130 siswa. Pengambilan sampel menggunakan teknik random sampling sederhana. Pengumpulan data menggunakan alat ukur tinggi badan dan berat badan serta kuesioner.Analisis data menggunakan univariat dan analisis bivariat. Hasll uji Chi square diketahui bahwa dari 130 siswa yang diteliti yang memiliki status gizi kurus sebanyak 23 orang $(17,7 \%)$, normal 91 orang $(70 \%)$, gemuk 16 orang $(12,3 \%)$. Adapun hubungan dengan status gizi remaja pada SMA N 5 Metro yaitu citra tubuh $\mathrm{p}$ value $=0,874$, pengetahuan gizi nilai $\mathrm{p}$ value $=0,765$ dan perilaku makan nilai 
$\mathrm{p}$ value $=0,354$. Dapat disimpulkan bahwa tidak terdapat hubungan antara citra tubuh, pengetahuan gizi dan perilaku makan terhadap status gizi remaja di SMA Negeri 5 Kota Metro. Adapun saran yaitu memberikan informasi kepada remaja terkait kebutuhan zat gizi serta perilaku makan yang baik guna menjaga agar tidak terjadi penyimpangan terkait citra tubuh.

Kata kunci : Status Gizi, Citra Tubuh, Pengetahuan Gizi, Perilaku Makan, Remaja.

\section{PENDAHULUAN}

Remaja adalah sumber daya manusia yang paling potensial dalam sebuah negara karena remaja merupakan generasi penerus bangsa. Remaja akan menjadi sumber daya manusia yang berkualitas jika sejak dini terpenuhi kebutuhan gizinya. Status gizi adalah ekspresi dari keadaan keseimbangan dalam bentuk variabel tertentu, atau perwujudan nutriture dalam bentuk variabel tertentu (Supariasa, dkk, 2012). Status gizi remaja berhubungan dengan berbagai macam faktor yang mempengaruhinya, di antaranya adalah asupan energi dan zat gizi, jenis kelamin, pendidikan, pengetahuan, perilaku makan, kebiasaan konsumsi serat (buah dan sayur), aktivitas fisik, perilaku, merokok, citra tubuh dan faktor genetik yaitu status gizi orang tua. Pemberian nutrisi pada kelompok remaja bertujuan untuk mencapai asupan nutrisi yang optimal dan seimbang untuk meningkatkan pertumbuhan dan kesehatan.Tujuan ini sering tidak tercapai sehubungan dengan praktek perilaku makan yang terganggu, gaya hidup dan asupan makan yang tidak adekuat. Remaja sering melakukan perilaku diet yang salah dan tidak sesuai dengan panduan dan rekomendasi yang berlaku.

Bentuk tubuh yang ideal merupakan hal yang diidam-idamkan hampir oleh semua orang, terutama bagi remaja yang mulai mengembangkan konsep diri dan juga hubungan heteroseksual. Pada masa remaja terjadi perubahan fisik, biologis, dan kognitif yang cepat dan drastis. Perubahan yang cepat ini menimbulkan respon tersendiri bagi remaja berupa tingkah laku yang sangat memperhatikan perubahan bentuk tubuhnya. Respon itu terwujud dalam bentuk penilaian atau evaluasi akan fisik tubuh mereka. Penilaian tersebut berupa perasaan puasa atau tidak puas akan keadaan tubuh dan penampilannya. Penilaian mengenai penampilan fisik ini disebut dengan citra tubuh (Muhith, 2015).

Citra tubuh adalah sikap, persepsi, keyakinan dan pengetahuan individu secara sadar atau tidak sadar terhadap tubuhnya meliputi ukuran, bentuk, struktur, fungsi, keterbatasan, makna dan objek yang kontak secara terus menerus baik masalalu maupun sekarang (Muhith, 2015). Banyak remaja yang tidak puas dengan penampilan dirinya sendiri, apalagi yang menyangkut tentang citra tubuh atau persepsi terhadap bentuk tubuhnya. Bentuk tubuh tinggi, langsing ataupun berotot merupakan hal yang diinginkan oleh para kaum remaja. Pada kenyataannya banyak remaja yang tidak puas dengan bentuk tubuhnya.

Sebagian besar remaja yang sering melakukan penilaian terhadap tubuhnya adalah wanita, dan termasuk golongan sosial-ekonomi menengah keatas dimana mereka sangat peduli akan bentuk tubuh dan berat badan mereka. Remaja yang memiliki citra tubuh negative dapat pula mengalami status gizi lebih 
akibat dari perilaku makan yang salah yaitu mengonsumsi makanan cepat saji ataupun makan melebihi kebutuhan tubuh dan citra tubuh yang negative juga membuat remaja tidak makan sesuai kebutuhannya. Masalah kurang gizi tersebut dapat berupa kekurangan energy dan protein, kurus, obesitas, maupun tinggi badan yang tidak sesuai dengan umur.

Perilaku makan adalah suatu tingkah laku yang dapat diamati yang dilakukan individu dalam rangka memenuhi kebutuhan makan yang merupakan kebutuhan dasar yang bersifat fisiologis. Remaja banyak mengalami perubahan-perubahan fisik maupun psikisnya. Semua hal tersebut mempengaruhi tingkah lakunya. Termasuk juga perilaku makannya, padahal pada tahap perkembangan ini remaja membutuhkan gizi yang cukup untuk menunjang pertumbuhannya. Remaja yang mempunyai perilaku makan yang buruk tidak lagi memperhatikan kandungan gizi dari makanan yang dikonsumsinya (Notoatmodjo, 2013). Keadaan ini membuat remaja memiliki resiko yang tinggi terhadap berbagai jenis penyakit akibat perilaku yang tidak sehat. Salah satu perilaku yang tidak sehat adalah perilaku makan. Berdasarkan latar belakang diatas perlu dilakukan penelitian untuk mengetahui hubungan citra tubuh, pengetahuan tentang gizi dan perilaku makan dengan status gizi remajadi SMA Negeri 5 Kota Metro tahun 2017.

\section{METODE}

Jenis penelitian yang digunakan dalam penelitian ini adalah kuantitatif, yang bertujuan untuk mengetahui hubungan citra tubuh, pengetahuan gizi dan perilaku makan terhadap status gizi pada remaja SMA Negeri 5 di Kota Metro tahun 2017. Menggunakan rancangan metode Crossectional adalah rancangan studi yang mempelajari hubungan penyakit dan pajanan dengan cara mengamati status penyakit dan pajanan factor penelitian pada suatu populasi secara bersamaan/serentak (Sugiyono, 2015), analisis data yang digunakan dalam penelitian ini adalah analisa kuantitatif.

\section{HASIL}

Tabel 1. Distribusi Status Gizi, Citra Tubuh, Pengetahuan Gizi dan Perilaku Makan Siswa SMAN 5 Metro tahun 2017

\begin{tabular}{llcc}
\hline \multicolumn{1}{c}{ Variabel } & Kategori & N & Proporsi (\%) \\
\hline Status Gizi & Kurus & 23 & 17,7 \\
& Normal & 91 & 70,0 \\
\multirow{4}{*}{ Citra Tubuh } & Gemuk & 16 & 12,3 \\
\multirow{5}{*}{ Pengetahuan Gizi } & Positif & 63 & 48,5 \\
& Negatif & 67 & 51,5 \\
& Baik & 34 & 26,2 \\
Perilaku Makan & Sedang & 96 & 73,8 \\
& Kurang & 0 & 0 \\
& Baik & 79 & 60,8 \\
& Tidak Baik & 51 & 39,2 \\
\hline
\end{tabular}

Tabel diatas menunjukkan bahwa dari 130 siswa SMA N 5 Metro yang diteliti yang memiliki status gizi kurus sebanyak 23 orang $(17,7 \%)$, normal sebanyak 91 orang (70\%), gemuk sebanyak 16 orang (12,3\%). Yang memiliki persepsi citra tubuh positif sebanyak 63 orang $(48,5 \%)$ 
dan 67 orang $(51,5 \%)$ memiliki persepsi citra tubuh negatif. Yang memiliki pengetahuan gizi baik sebanyak 34 orang $(26,2 \%), 96$ orang $(73,8 \%)$ memiliki persepsi pengetahuan gizi sedang dan tidak ada yang memiliki pengetahuan gizi yang kurang. Yang memiliki perilaku makan yang baik sebanyak 79 orang $(60,8 \%)$ dan 51 orang $(39,2 \%)$ memiliki perilaku makan yang tidak baik.

\begin{tabular}{|c|c|c|c|c|c|c|c|c|}
\hline \multirow[t]{2}{*}{ Variabel } & \multirow[t]{2}{*}{ Kategori } & \multicolumn{6}{|c|}{ Status Gizi } & \multirow{2}{*}{$\begin{array}{c}\text { P- } \\
\text { Value }\end{array}$} \\
\hline & & Kurus & $\%$ & Normal & $\%$ & Gemuk & $\%$ & \\
\hline \multirow[t]{2}{*}{ Citra Tubuh } & Positif & 12 & 19 & 44 & 69,8 & 7 & 11,1 & 0,874 \\
\hline & Negatif & 11 & 16,4 & 47 & 70,1 & 9 & 13,4 & \\
\hline Pengetahuan & Baik & 6 & 17,6 & 25 & 73,5 & 3 & 8,8 & 0,765 \\
\hline Gizi & Sedang & 17 & 17,7 & 66 & 68,8 & 13 & 13,5 & \\
\hline Perilaku & Baik & 12 & 15,2 & 55 & 69,6 & 12 & 15,2 & 0,354 \\
\hline Makan & $\begin{array}{l}\text { Tidak } \\
\text { baik }\end{array}$ & 11 & 21,6 & 36 & 70,6 & 4 & 7,8 & \\
\hline
\end{tabular}

Hasil analisa hubungan citra tubuh terhadap satatus gizi adalah bahwa siswa dengan citra tubuh positif ditemukan sebanyak 12 responden mengalami status gizi kurus, 44 responden mengalami status gizi normal, dan tujuhresponden mengalami status gizi gemuk. Sedangakan siswa dengan citra tubuh negatif ditemukan sebanyak 11 responden mengalami status gizi kurus, 47 responden mengalami status gizi normal, dan sembilanresponden mengalami status gizi gemuk. Hasil uji statistik dengan metode chi square menunjukkan bahwa nilai $p$ value 0,874 . Dapat disimpulkan bahwa hipotesis nol diterima, maka hal tersebut menunjukkan tidak adanya hubunganantara citra tubuh terhadap status gizi siswa SMA Negeri 5 Kota Metro tahun 2017.

Hasil analisa hubungan pengetahuan gizi terhadap satatus gizi adalah bahwa siswa dengan pengetahuan gizi yang baik ditemukan sebanyak enamresponden mengalami status gizi kurus, 25 responden mengalami status gizi normal, dan tigaresponden mengalami status gizi gemuk. Sedangkan siswa dengan pengetahuan gizi yang sedang ditemukan sebanyak 17 responden mengalami status gizi kurus, 66 responden mengalami status gizi normal, dan 13 responden mengalami status gizi gemuk.

Hasil uji statistik dengan metode chi square menunjukkan bahwa nilai $p$ value $=0,765$. Dapat disimpulkan bahwa hipotesis nol diterima, maka hal tersebut menunjukkan tidak adanya hubunganantara pengetahuan gizi terhadap status gizi siswa SMA Negeri 5 Kota Metro tahun 2017.

Hasil analisa hubungan perilaku makan terhadap satatus gizi adalah bahwa siswa dengan perilaku makan yang baik ditemukan sebanyak 12 responden mengalami status gizi kurus, 55 responden mengalami status gizi normal, dan 12 responden mengalami status gizi gemuk. Sedangkan siswa dengan perilaku makanyang tidak baik ditemukan sebanyak 11 responden mengalami status gizi kurus, 36 responden mengalami status gizi normal, dan empatresponden mengalami status gizi gemuk. Hasil uji statistik dengan metode chi square menunjukkan bahwa nilai $p$ value 0,354. Dapat 
disimpulkan bahwa hipotesis nol diterima, maka hal tersebut menunjukkan tidak adanya

\section{PEMBAHASAN}

Dari hasil analisis data diatas, diketahui bahwa masih adanya siswa yang memiliki persepsi negatif tentang citra tubuhnya, diantaranya tidak menyukai tubuh bagian tengah. Menurut Muhith (2015), adanya perubahan persepsi tentang tubuh yang diakibatkan oleh perubahan ukuran, bentuk, struktur, keterbatasan, makna dan objek yang sering kontak dengan tubuh dapat mengakibatkan gangguan citra tubuh. Gangguan tersebut akibat kegagalan dalam penerimaan diri akibat adanya persepsi yang negatif terhadap tubuhnya secara fisik. Persepsi tubuh secara fisik berkaitan dengan bagaimana kita mempersepsikan diri kita secara fisik. Pandangan yang realistis terhadap dirinya menerima dan mengukur bagian tubuhnya akan lebih rasa aman sehingga terhindar dari rasa cemas dan meningkatkan harga diri.

Pengetahuan gizi siswa SMAN 5 tergolong baik, dibuktikan dari hasil jawaban kuesioner yang dibagikan. Pengetahuan gizi yang baik diharapkan mempengaruhi konsumsi makanan yang baik sehingga dapat menuju status gizi yang baik pula. Pengetahuan gizi merupakan faktor yang penting dalam masalah kurang gizi yang berpengaruh terhadap sikap dan perilaku dalam memilih makanan dan dalam pengolahan sehingga menurunkan kadar kandungan gizi (Azwar, 2016). Namun pengetahuan gizi siswa tidak sejalan terhadap perilaku makan mereka. Masih banyaknya siswa yang melewati waktu makan merupakan salah satu perilaku makan yang kurang baik. Tidak sedikit survei yang mencatat ketidakcukupan asupan zat gizi para hubungan antara perilaku makan terhadap status gizi siswa SMA Negeri 5 Kota Metro tahun 2017.

remaja.Mereka bukan hanya melewatkan waktu makan (terutama sarapan) dengan alasan sibuk, tetapi juga terlihat sangat senang mengunyah junk food. Kekhawatiran menjadi gemuk telah memaksa mereka untuk mengurangi jumlah pangan yang seharusnya disantap (Arisman, 2010).

\section{KESIMPULAN}

Tidak terdapat hubungan antara citra tubuh, pengetahuan gizi dan perilaku makan terhadap status gizi remaja di SMA Negeri 5 Kota Metro.

\section{SARAN}

Memberikan informasi terkait citra tubuh, kebutuhan zat gizi dan perilaku makan yang baik bagi remaja. Pemberian informasi ini bisa dilakukan oleh pihak sekolah bekerjasama dengan pihak Puskesmas Yosomulyo yang merupakan Puskesmas yang membina SMA N 5 Metro dan UKS di SMA N 5 Kota Metro. Perlu dilakukan penelitian lanjutan untuk meneliti tentang faktor lain yang tidak diteliti dalam penelitian ini, seperti variabel sosial ekonomi dan perhitungan kalori.

\section{DAFTAR PUSTAKA}

Arisman, (2010), Gizi Dalam Daur Kehidupan, EGC, Jakarta

Azwar, Saifuddin, (2016), Sikap Manusia Dan Teori Pengukurannya, Pustaka Pelajar, Yogyakarta

Muhith, Abdul, (2015), Pendidikan Dan Keperawatan Jiwa, Andi Offset, Yogyakarta

Notoatmodjo, Soekidjo, (2013), Promosi Kesehatan Dan Perilaku Kesehatan, Rineka Cipta, Jakarta 
Sugiyono, (2015), Metode Penelitian Kuantitatif, Kualitatif dan $R \& D$, Alfabeta, Bandung

Supariasa, I Dewa Nyoman, Bachyar Bakri, Ibnu Fajar, (2012), Penilaian Status Gizi, EGC, Jakarta.

Maryusman, T., Mawapi, Y. P., \& Syah, M. N. H. (2020). Apakah Citra Tubuh dan Risiko Gangguan Makan Berisiko Anemia? Studi Kasus Pada Siswa Putri. Ghidza: Jurnal Gizi dan Kesehatan, 4(1), 22-31.

Handayani, E. Y., \& Rumiati, Z. (2020). Hubungan Status Gizi Remaja terhadap Kejadian Anemia Pada Remaja Putri Di SMPN 02 Rambah Hilir Kabupaten Rokan Hulu. Jurnal Martenity and Neonatal, 3(1), 15.

Rahmawati, A. N. (2017). PENGAMBILAN KEPUTUSAN

DALAM PEMILIHAN PANGAN

LOKAL OLAHAN DAN POLA KONSUMSI PANGAN RUMAH TANGGA SEKITAR AGROINDUSTRI BIHUN TAPIOKA DI KOTA METRO (Decision Making In the Selection of Processed
Local Foods and the Pattern of Household Food Consumption around Agroindustry of Tapioca Vermicelli In Metro City).

FISKASARI, S. R. (2019). HUBUNGAN DEPRESI, ANSIETAS, DAN STRES DENGAN STATUS GIZI PADA MAHASISWA FAKULTAS KEDOKTERAN UNIVERSITAS LAMPUNG.

Rahmawati, A. N. (2017). PENGAMBILAN KEPUTUSAN DALAM PEMILIHAN PANGAN LOKAL OLAHAN DAN POLA KONSUMSI PANGAN RUMAH TANGGA SEKITAR AGROINDUSTRI BIHUN TAPIOKA DI KOTA METRO (Decision Making In the Selection of Processed Local Foods and the Pattern of Household Food Consumption around Agroindustry of Tapioca Vermicelli In Metro City).

AYESHA, K. (2019). GAYA HIDUP DALAM MENGONSUMSI SAYUR DAN BUAH SERTA TINGKAT KECUKUPAN GIZI ANAK USIA SEKOLAH DASAR DI KOTA METRO. 